\title{
Developing Students' Motivation at MTS Negeri Papi Enrekang in Speaking English through Selected Games
}

\author{
Umiyati Jabri \\ STKIP Muhammadiyah Enrekang \\ Correspondence Email: umiyatijabri@gmail.com
}

\begin{abstract}
This research aimed at finding whether the students were motivated to speak English by using communication games and also finding out students' part. The sample consisted of 30 students in participation in the classroom. In this reaserch the data were obtained through questionnaire (one and two). The result of the questionnaire's description showed that the motivation of students was positive. It can be concluded that students are motivated to learn English through communication games. It was proved from the findings the of the students' averange score that was 89.6 and the mean score was 4.48. The level of motivation was considered very high based on Likert Scale, and the result of the Questionnaire preference showed that the students prefer jigsaw as communication games in speaking English with percentage, Jigsaw (56.7\%), Giving Direction (33.3\%), and Picture Pairs (10\%).
\end{abstract}

\section{Keywords: Speaking skills, Students'motivation, game}

\section{INTRODUCTION}

Nowadays, learning English is focused on how to students use the English as a target language in daily life conversation not only focus on its grammar itself. Talking about learning a language, we are concentrate on its skill to mastering the language. Skills in learning English are categorized as productive and receptive skills. Speaking is involved in productive skill, and it plays crucial part in learning English, because students need this abilities to carry out conversation. It is a collaborative process of building meaning that contains producing, receiving, and processing information. "Speaking is a skill which deserves attention every bit as much as literary skills, in both first and second language. It is the skill students are frequently judged. It is also the vehicle par excellent of social solidarity, social ranking, professional advancement and business" (Jones, 1989).

Students need this skill of English speaking in order they could communicate with other. But to master those skill students also need high motivation or interest in learning process. Motivation is really needed because it can influence how the students acquire knowledge in the classroom. In fact, the students are more involved if they have high motivation then the teaching and learning process will be active. 
This research is taken at MTS Negeri Papi Enrekang. Before doing research, researcher did pre-observation to the eighth grade students during their English class. Problems found by researcher are (2) students are unmotivated to study English, (3) students are difficult to speak English, (4) lack of confidence and anxiety of the students, and (5) students inactive in learning process. From the four problems mentioned before can be concluded that there are two main points of the problems namely motivation and speaking. Based on the observation, the researcher noted that most of the students have low motivation. It was caused by their lack of selfconfidence and anxiety. They are shame when they could not speak, feeling fear in making mistake of vocabulary and grammar when they speak. The factor also was influenced from the teacher. She was hardly to choose and create teaching techniques and activities because the lack of facilities, and also students afraid to make mistakes in speaking. This assumption was supported by the teachers of MTS Negeri Papi Enrekang as well. They stated that they need method to motivate and develop the students' motivation to speak English.

Because the subject of this research are still in teenagers where they are still young and high desire to play. Indeed, young learners of English may also giggle when they are embarrassed or when they are unable to understand the lesson (Byung, 2004).

According to Hammer, Motivation is a kind of internal drive that encourages somebody to pursue a course of action (Harmer, 1991: 3). Because the motivation is related to the internal drive of somebody, that the teacher duty to make that the internal drive is still on while learning and teaching process. Indeed, Wright (1987:53) stated that a primary function of teachers' management role is to motivate the learners who are demotivated and to nurture those who are already motivated to the task of learning a foreign language.

The researcher choose games as a technique to develop their motivation in learning English. Kim (1993:1) states that "there is common perception that all learning should be serious and solemn in nature and that if one is having fun and there is hilarity and laughter, then it is not really learning. This is possible to learn language as well as enjoy oneself at the same time. One of the best ways of doing this is through games".

Game means "an activity with rules, a go al and an element of fun" (Hadfield, 1996). In addition, game is "an activity in which the learners play and usually interact with others" (Wright et al., 2006). Because game is a fun activity (Ismail, 2017), it could stimulate the students in learning English especially in speaking without fear or shy.

Ersoz (2000: 1) stated that "games are invaluable as they give the students a break and at the same time allow students to practice language skills. Games are highly motivating since they are amusing and at the same time challenging". Game could bring fun way in learning so that it could decrease the anxiety of the students and also make students fell free in expressing their ideas. Games are also valuable to encourage students in interacting each other orally in fun way. Through games, the students could speak to interact with others using English to express their ideas, feeling and thought. Indeed, they shares lesson to other through communication in interesting or fun way. It will give students a chance to practice English in speaking in learning process. Furthermore, The study from Dewi et al (2017) revealed that using communicative game as means of instruction improved the students' achievement and results of speaking skill. Students enjoyed their lesson and got more motivation, interest and confidence through their learning. Therefore, communicative game should be 
applied as designed activities in teaching (Ismail \& Mustakim, 2018).

According to the case above the researcher carries out a research entitle "Developing Students' Motivation at MTS Negeri Papi Enrekang in Speaking English through Selected Game.".

\section{METHODOLOGY}

This research would follow the principal working of classroom action research (CAR) that contains of four stages; they are: Planning, Implementation of Action, Observation, and Reflection. According to Sagor, The primary reason for engaging in action research is to assist the "actor" in improving and/or refining his or her actions" (Sagor, 2000). This research would be held around two cycles. They are first and second cycle and each cycle was the series of activities which have close relation. Where, the realization of the second cycle was continued and repairing from the first cycle.

This research would be conducted in MTS Negeri Papi where be held on August-November for cycle one while the cycle two would be conducted on October until November. The subject of this research was eighth grade students of MTS Negeri Papi. There are two variables in this research. They are independent variables which is the use of selected games and dependent variable which is students' motivation in speaking English.

The researcher used two questionnaire. Questionnaire first to collect the data of the research, the researcher would use communication games and two questionnaires. The first questionnaire consists of 20 items. Ten items are in positive statement and ten of them are in negative ones. The questionnaire would use attitude scale. Strongly agree, agree, undecided (doubtful), disagree and strongly disagree are the option for the statements. The second questionnaire consists of four items aiming at finding out the type of communication games that students prefer. Second,

In collecting the data, this research would be conducted in four stages; Planning, Action, Observation, and Reflection each cycle. But in cycle II would be needed some repairs and adding as deals the condition in learning process after seeing their result of cycle I.

\section{RESULT}

\section{Cycle I}

The first cycle was held in three meetings. Based on the these meetings, the researcher found during the act phase the fact that The students cannot find many differences between 2 pictures they just found less than ten while they should find ten differences. Some of students in doing a game were silent and looked like confused to complete their games. Some of the students used Indonesian to give his/her friends instruction in order to reach the goal of the game. Starting from those conditions above, the writer formulates these for next cycle: Teacher should not use a difficult goal of the game. The students like a picture that writer give to them. Because they said that it is interesting, color full and simple. Teacher should be more creative in choose the suitable pictures. To make the learning more effective, the writer still uses panda and school sketch.

\section{Cycle II}

The second cycle was held in three meetings. Result of the writer during the act phase as follow: The students can find reach the goal all of the games. Some of students in doing a game were very active and never confused. All of the pairs and groups made cooperation each other. The students were able to reach a goal of the game before the time was up. The writer knows that a communication games can stimulate students to speak English. The students enjoy the learning process while doing games and automatically the 
students' judge that English is a fun. For the best result the teacher should be choose an interesting picture to attract the students in learning and motivate them in speaking.

\section{Result of questionnaire}

The data analysis of motivation of VII students at SMPN 23 Makassar to speak English by communication games considered as very high. The result of questionnaire showed that the students' average score was 89.6 and the students' mean score was 4.48. The data below shows the students' motivation.

Table 1 The data analysis of students' motivation

\begin{tabular}{|c|c|c|c|c|c|c|}
\hline NO & $\begin{array}{c}\text { STATEMENTS } \\
\end{array}$ & $\mathbf{S A}$ & $\mathbf{A}$ & $\mathbf{U}$ & $\mathbf{D}$ & SD \\
\hline 1 & $\begin{array}{l}\text { Communication games make me enthusiastic in } \\
\text { speaking English }\end{array}$ & 18 & 11 & 1 & 0 & 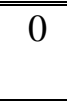 \\
\hline 2 & Communication games make me active to speak English & 15 & 14 & 1 & 0 & 0 \\
\hline 3 & $\begin{array}{l}\text { Communication games can improve the speed and } \\
\text { accuracy in speaking English }\end{array}$ & 17 & 13 & 0 & 0 & 0 \\
\hline 4 & Through communication games, I feel the time goes fast & 18 & 8 & 4 & 0 & 0 \\
\hline 5 & $\begin{array}{l}\text { Communication games are very interesting to be used in } \\
\text { teaching speaking }\end{array}$ & 22 & 5 & 3 & 0 & 0 \\
\hline 6 & $\begin{array}{l}\text { Communication games are very good to stimulate me in } \\
\text { expressing my idea in speaking English }\end{array}$ & 16 & 13 & 1 & 0 & 0 \\
\hline 7 & $\begin{array}{l}\text { Through communication games, I have never felt } \\
\text { awkward in speaking English }\end{array}$ & 10 & 15 & 5 & 0 & 0 \\
\hline 8 & $\begin{array}{l}\text { Through communication games, I felt free to express } \\
\text { my idea in speaking English }\end{array}$ & 9 & 18 & 3 & 0 & 0 \\
\hline 9 & $\begin{array}{l}\text { I am not shy at all to speak English through } \\
\text { communication games }\end{array}$ & 15 & 7 & 8 & 0 & 0 \\
\hline 10 & $\begin{array}{l}\text { I am very pleased if communication games are applied } \\
\text { in teaching speaking }\end{array}$ & 22 & 6 & 2 & 0 & 0 \\
\hline 11 & $\begin{array}{l}\text { I am not enthusiastic in speaking English through } \\
\text { Communication games }\end{array}$ & 0 & 0 & 1 & 5 & 24 \\
\hline 12 & $\begin{array}{l}\text { Communication games do not enable us to speak } \\
\text { English actively }\end{array}$ & 0 & 0 & 1 & 7 & 22 \\
\hline 13 & $\begin{array}{l}\text { Communication games cannot improve the speed and } \\
\text { accuracy in speaking English }\end{array}$ & 0 & 0 & 1 & 12 & 17 \\
\hline 14 & $\begin{array}{l}\text { It is very boring to speak English through } \\
\text { Communication games }\end{array}$ & 0 & 0 & 1 & 7 & 22 \\
\hline 15 & $\begin{array}{l}\text { Communication games are not interesting to be used in } \\
\text { teaching speaking }\end{array}$ & 0 & 0 & 3 & 12 & 15 \\
\hline 16 & $\begin{array}{l}\text { I am lack of ideas in Speaking English through } \\
\text { communication games }\end{array}$ & 0 & 0 & 2 & 14 & 14 \\
\hline 17 & $\begin{array}{l}\text { Communication games do not make me free to express } \\
\text { my ideas }\end{array}$ & 0 & 0 & 5 & 10 & 15 \\
\hline 18 & $\begin{array}{l}\text { Communication games make me not awkward in } \\
\text { speaking English }\end{array}$ & 0 & 0 & 1 & 13 & 16 \\
\hline 19 & $\begin{array}{l}\text { In communication games, I am ashamed if I make } \\
\text { mistakes in speaking }\end{array}$ & 0 & 0 & 5 & 12 & 13 \\
\hline 20 & $\begin{array}{l}\text { I am not pleased if communication games are applied in } \\
\text { teaching speaking }\end{array}$ & 0 & 1 & 1 & 11 & 17 \\
\hline
\end{tabular}


1. The Types of Communication

\section{Games that Students Prefer}

The description of data collected through questionnaire 2 that the students of VIII $^{\mathrm{H}}$ at SMPN 23 Makassar prefer jigsaw as communication games in speaking English with percentage, Jigsaw (56.7\%), Giving Direction (33.3\%), and Picture Pairs (10\%).

\section{DISCUSSION}

It was found that the students are active in learning to speak English through commmunication games. As stated that the motivation of VIII ${ }^{\mathrm{H}}$ students at SMPN 23 Makassar was very high. It was proved by the students' average score was 89.6 and the mean score was 4.48. It was also interpreted into the level of motivation considered as very high.

\section{CONCLUSION}

The motivation of students were positive, it can be interpreted that they are motivated to learn English through communication games. Students feels directly involve in teaching process in order to increase their motivation to speak English. Students' participation was very active to speak English by using communication games.

\section{REFERENCES:}

[1] Byung Eun-, Cho. (2004). Issues Concerning Korean Learners of English: English Education in Korea and Some Common Difficulties of Korean Student. The East Asian Learner, 1(2).

[2] Dewi, Ratna Sari, Kultsum Ummi and Ari Armadi.. (2017). Using
Communicative Fames in Improving Students' Speaking. Canadian Center of Science and Education. English Language Teaching;10 (1);

[3] Ersoz, Adyan. (2000). Six Games for the EFL/ESL Classroom. Retrieved on Wednesday $9^{\text {th }} 2011$, from http:/iteslji.org/lessons/ErsozGames.html

[4] Hadfield, J. (1996). Intermediate Communicative Games. Edinburg: Addison Wesley Longman Ltd.

[5] Harmer, Jeremy. (1991). The Practice of English Language Teaching. New York: Longman Group UK Limited.

[6] I Ismail., Mustakim.( 2018). Fundamental English Conversation. CV. Rasi Terbit.

[7] I Ismail. (2017). The Contribution of English Gossip Magazine on Students' Enthusiasm in Speaking Ability. Edumaspul-Jurnal Pendidikan. Vol. 2. (1), 1-14.

[8] I Ismail, U Jabri, R Rahmat, M Musdalifah (2017) Rubrics-Based Assessment as a Teaching Strategy of Writing Journal for Novice Authors. INTERNATIONAL CONFERENCE ON EDUCATION.

[9] Jones, Rhodri. (1989). Speaking and Listening. London: John Murray Publishers Ltd.

[10] Kim, lee su . (1993). Creative Games for the Language Class. Retrivied on Sunday, October $8^{\text {th }} 2017$, from http:/www.teflgames.com/why.html

[11] Sagor,R. (2000). Guiding School Improvement with Action Reasearch. USA: Association for Supervision and 
[12] Curriculum Development Retrieved from http://www.ascd.org/ publications/books/100047/chapters/ What-Is-Action-

Research\%C2\%A2.aspx

[13] Wright, Tony. (1987). Roles of Teachers and Learners. Oxford: Oxford Press
[14] Wright, A. (2006). Games for Language Learning (3rd ed.). Cambridge: Cambridge University Press.

[15] Ersoz, Adyan. (2000). Six Games for the EFL/ESL Classroom. Retrieved on Sunday, October $8^{\text {th }} 2017$, from http:/iteslji.org/lessons/Ersoz-

Games.html 